\title{
Identidades judías en la Europa tardoantigua: Erwin Goodenough y sus ecos
}

\section{Jewish identities in Late Ancient Europe: Erwin Goodenough and its echoes}

\author{
Rodrigo Laham Cohen \\ r_lahamcohen@hotmail.com \\ Universidad de Buenos Aires - Instituto Multidisciplinario \\ de Historia y Ciencias Humanas, Argentina
}

Recepción: 12 Marzo 2020

Aprobación: 08 Septiembre 2020

Publicación: 22 Septiembre 2021

Cita sugerida: Laham Cohen, R. (2021). Identidades judías en la Europa tardoantigua: Erwin Goodenough y sus ecos. Sociedades Precapitalistas, 11, e063. https://doi.org/10.24215/22505121e063
Resumen: El objetivo de este trabajo es presentar, por un lado, el derrotero historiográfico de los debates en torno al tipo de judaísmo que existía en Europa en la Antigüedad Tardía y, por el otro, desarrollar algunas definiciones sobre el camino que consideramos adecuado para recuperar la historia de los colectivos judíos europeos tardoantiguos. El texto se estructura en torno a la obra de Erwin Goodenough, quien tempranamente puso en entredicho la tesis tradicional que concebía una rápida expansión del movimiento rabínico, tanto en Palestina como en la Diáspora y, además, consideró la persistencia de un judaísmo alternativo, de corte helenístico y místico, hasta bien avanzada la Antigüedad Tardía. Se indagan, también, otras respuestas ensayadas en tiempos más cercanos, siempre en relación con la vida de los judíos y las judías en la Europa tardoantigua.

Palabras clave: Goodenough, Judaísmo rabínico, Judaísmo europeo, Antigüedad Tardía.

Abstract: The aim of this paper is twofold. Firstly, we present a historiographical analysis of the debates around the type of Judaism that existed in Europe in late antiquity. Secondly, we present some definitions on the approach that we consider appropriate with which to trace the history of late ancient European Jewish communities. The text is structured around the work of Erwin Goodenough, who early on called into question the traditional thesis that posited a rapid expansion of the rabbinic movement, both in Palestine and throughout the diaspora and, furthermore, asserted the persistence of an alternative Judaism Hellenistic and mystical - right until the end of late antiquity. We also present other more recent interpretations in relation to the life of the Jews in late-ancient Europe.

Keywords: Goodenough, Rabbinic Judaism, European Judaism, Late Antiquity.

\section{Introducción}

Definir el perfil del judaísmo en la Antigüedad Tardía es un desafío decididamente complejo. De hecho, referir a $j$ udaismo tardoantiguo implica, en 
algún punto, una toma de posición en favor de la existencia de un colectivo único, noción que, en parte, difumina implícitamente las divergencias regionales. ${ }^{1}$ Ciertamente, delimitar el judaísmo en la actualidad también conllevaría cientos de páginas y posiciones encontradas. Pero en el caso tardoantiguo en general y europeo en particular el problema es mayor por la acuciante falta de fuentes. En efecto, no han sobrevivido textos producidos por judíos europeos en el período, si bien tres obras - de anónima autoría y sobre las que hablaremos luego- han sido consideradas, por una parte de la crítica, como producidas por judíos. El único registro escrito disponible -siempre hablando de Europa- es el epigráfico, compuesto principalmente por inscripciones funerarias.

La irrupción del judaísmo rabínico es, sin duda, el fenómeno más importante del período tardoantiguo, obviamente en lo que se refiere a la historia de los judíos y las judías. Los textos rabínicos iniciales (Mishná, Tosefta, Talmud Yerushalmi, Talmud Bavli, entre otros) presentan la imagen de una rápida (y uniforme) imposición del rabinismo. Es tal el afán por mostrarse como el movimiento hegemónico que -más allá de ciertas grietas por las cuales es posible observar la disidencia y la multiplicidad- los rabinos proyectaron la noción de un grupo consolidado y triunfante (en Palestina y en la Diáspora) ${ }^{2}$, incluso antes de la propia génesis de lo que hoy conocemos como movimiento rabínico. Esta visión, que sobrevivió en la tradición, fue recuperada en tiempos contemporáneos por los trabajos producidos en el marco de la Wissenschaft des Judentums, el movimiento orientado a profesionalizar los estudios judaicos en el XIX. Tal perspectiva, de hecho, persiste aún hoy en una parte muy importante de la crítica. Por otro lado, quienes han dudado de un rápido triunfo rabínico en Europa no han realizado demasiados esfuerzos para comprender cómo era aquel judaísmo pre-rabínico; aspecto entendible, insistimos, dada la ya mentada carencia de fuentes.

El objetivo de este trabajo será analizar críticamente las investigaciones más importantes que han indagado la temporalidad y el modo en el que se produjo el proceso de rabinización de la Diáspora europea. Tangencialmente, dada la falta de espacio, exploraremos cómo se han concebido las comunidades judías europeas en los momentos previos al arribo del rabinismo. La pionera y muy resistida obra de Erwin Ramsdell Goodenough (1893-1965) nos ayudará a estructurar el derrotero aquí propuesto. Cerraremos el artículo presentando el camino por el cual, entendemos, deberían avanzar las investigaciones futuras.

\section{Los silencios occidentales y la "imposición” de Oriente}

En la segunda mitad del siglo XX una parte importante de la historiografía intentó deconstruir la idea de que los judíos de Europa fueron tempranamente rabinizados. Tres postulados fueron, así, puestos en tela de juicio: 1) la rápida y completa rabinización de Palestina; 2) el alto grado de vinculación entre los colectivos de la Diáspora y la Tierra de Israel; 3) la ausencia de culturas judías específicas y dinámicas en Europa con capacidad de resistir cambios provenientes desde Palestina.

Que se haya pensado en una rabinización temprana de la Diáspora responde, en parte, al problema ya mencionado de las fuentes. No es posible, en el estado actual de nuestros conocimientos, discernir si los judíos europeos decidieron no dejar testimonios escritos -más allá de la epigrafía- y optaron 
por volcar la memoria exclusivamente en la oralidad. Desde nuestra perspectiva, sí habrán existido obras escritas por judíos que, por discontinuidad del asentamiento, debilidad política, violencias externas, decisiones comunitarias o simplemente azar, no llegaron hasta nuestros días. Pero más allá del debate, el silencio documental ha permitido que la literatura rabínica producida en Palestina y en Mesopotamia sea vislumbrada como el medio más eficiente para complementar y contrastar la escasa información disponible sobre los judíos europeos tardoantiguos. Para empeorar el panorama, las fuentes europeas más profusas del periodo son cristianas y se orientan a polemizar con los judíos sin destinar esfuerzos para describirlos. Nos hablan más del judio hermenéutico ${ }^{3}$ que de sujetos de carne y hueso. ${ }^{4}$

La arqueología podría haber ayudado a subsanar los silencios, pero la escasez de hallazgos tampoco permitió profundizar las pesquisas. Acaso uno de los aspectos de mayor relieve que puede deducirse de los restos arqueológicos de sinagogas europeas como las de Ostia o Saranda es la existencia de ciertos patrones "judíos" suprarregionales en el marco de un amplio uso de elementos locales no-judíos. En otras palabras, la sinagoga de Ostia se asemeja -en cuanto a técnicas de construcción y estilos decorativos- a edificios no judíos de la ciudad, pero comparte con otros edificios de culto judíos de distintas regiones algunos elementos específicos, como el lugar reservado para la Torá o cierto repertorio artístico común, como la Menorá o las especies utilizadas en Sucot. Las catacumbas judías de Roma, para dar otro ejemplo, vuelven a mostrar la combinación de elementos artísticos grecolatinos tradicionales -incluso, aunque debatido, la representación de dioses del panteón clásico- ${ }^{5}$ con elementos típicos del judaísmo. Los restos arqueológicos, entonces, muestran tanto la interacción como la existencia de ciertos aspectos identitarios que trascienden el marco regional. No obstante, más allá de estos aportes, los restos materiales de los judíos y las judías europeos/as no permiten (ni en la Diáspora ni en Palestina) considerar si su judaísmo era rabínico o no. En breve veremos cómo la detección de representaciones artísticas en sinagogas y sitios funerarios judíos tardoantiguos desencadenó fuertes tensiones sobre los alcances y las limitaciones del rabinismo no sólo en la Diáspora sino, sobre todo, en la propia Tierra de Israel

El estudio de la epigrafía judía europea -principalmente la más abundante, en Roma- sí presentaba voces judías locales que permitían reconstruir, a pesar de su laconismo, parte de la historia de las comunidades. Más aún: la ausencia de referencias a rabinos en las más de 600 inscripciones de la urbs aeterna (datadas ca. siglos II y V e.c. $)^{6}$ puso frente a ojos de los especialistas el desafío de conciliar tal organización con las que textos como el Talmud de Jerusalén presentaban. ${ }^{7}$ Títulos como "arconte", "gerusiarca" o "madre de la sinagoga" eran difíciles de encuadrar en la literatura rabínica. La epigrafía judía europea tardoantigua, entonces, parecía presentar un tipo de organización que no coincidía con el modelo rabínico. A ello se sumaba la ínfima presencia del hebreo y del arameo en la primera parte del milenio y la ausencia de citas de la literatura rabínica, incluso de textos tempranos como la Mishná. Tal realidad abría las puertas a pensar, cuanto menos, que el fenómeno rabinizador había sido o bien lento o bien tardío. De hecho, sólo las inscripciones datadas hacia el siglo IX estaban completamente escritas en hebreo y presentaban, en algunos casos, contenido talmúdico. ${ }^{8}$ No 
obstante, más allá de las tempranas sugerencias de Blau, hubo que esperar hasta la segunda parte del siglo XX para que ciertos especialistas, entre los que resalta Goodenough, imaginaran un judaísmo diaspórico sui generis.

Aunque, como adelantamos, la mayoría de los textos cristianos del período no ofrecían auxilio, por su carácter tópico, en la reconstrucción de la fisonomía de las comunidades judías europeas, algunos documentos trascendían los topo $i$ adversus Iudaeos. Pero precisamente tales evidencias planteaban interrogantes a la rabinización de Europa. En general, sin embargo, se los leyó como otra muestra del desinterés (y desconocimiento) cristiano por comprender las estructuras judías. Sólo para dar un ejemplo, las normas del Código Teodosiano generaban desconcierto al referirse a archisinagogos, principales, ancianos y presbíteros, entre otros, pero no a rabinos. Hablaban, también, de patriarcas en plural (C.Th. XVI, 8, 1 y XVI, 8, 13), cuando sólo se tiene conocimiento de la existencia de un patriarca (y en Palestina). ${ }^{9}$ Incluso en un documento tan tardío como la carta de privilegio, de 1084, destinada a los judíos de Espira el obispo Rüdiger se refería al líder de la comunidad local como archisinagogo y no como rabino. ${ }^{10}$

El análisis de textos producidos por judíos europeos en los inicios del segundo milenio ha operado, sólo en los últimos decenios, como una herramienta adicional para repensar el proceso de rabinización. En efecto, ciertos especialistas consideraron que en tales textos se detectaban tradiciones (denominadas minaguim) que no parecían derivadas del material rabínico (y en ocasiones eran confrontadas por los propios rabinos), hecho que fue explicado, en ocasiones, por la persistencia de costumbres previas a la rabinización. ${ }^{11}$

Este último aspecto debe hacernos recordar la cautela de Hezser cuando sugiere que no se debe exagerar la diferencia entre grupos rabínicos y no rabínicos. ${ }^{12}$ Porque si bien consideramos que ambos tipos (y sus subtipos) de judaísmos fueron diversos, debemos pensar también en la posibilidad de grises producto de la convivencia y yuxtaposición de influencias. En tal sentido, es importante que no perdamos de vista que el movimiento rabínico tampoco fue plenamente homogéneo y ello debe alejarnos de observarlo como un conjunto único, orgánico y centralizado de ideas. Las disonancias, entonces, podrían provenir no de la dicotomía rabínico / no-rabínico sino de disensiones en el mismo seno de los colectivos rabínicos. En esa línea, para dar otro ejemplo, Miller (1999 y 2004) consideró que era posible pensar en rabinos con injerencia parcial en la sinagoga, coexistiendo con otros liderazgos, sin que ello implicara que la sinagoga arqueológica hubiera sido una institución completamente alógena a los rabinos. ${ }^{13}$

Ahora bien, más allá de estos matices, lo cierto es que diversos autores, desde mediados del siglo XX, vieron una seria dificultad para conmensurar el relato rabínico con la realidad arqueológica, epigráfica e incluso literaria, tanto en Palestina como en la Diáspora. Esto llevó a ciertas operaciones historiográficas que intentaron comprender las razones de aquello que observaban como disonancias. Antes de lanzarnos al derrotero historiográfico sobre el judaísmo europeo tardoantiguo debemos comenzar por Palestina dado que, como anticipamos, en los últimos decenios se cuestionó la velocidad de la rabinización en la propia Tierra de Israel y ello tiene consecuencias claras para la comprensión del momento de llegada del rabinismo a la Diáspora en general y a Europa en particular. 


\section{La (lenta) rabinización del judaísmo palestinense}

Seremos breves aquí por una cuestión de economía de espacio y, también, porque no es el punto central del artículo. Como ya adelantamos, durante gran parte del siglo XX e incluso hoy, un grupo importante de historiadores e historiadoras insistieron en la idea de que, caído el Segundo Templo, el grupo rabínico se consolidó rápidamente y se hizo con el control del judaísmo en toda la Tierra de Israel (y, casi inmediatamente, en la Diáspora). Esta lectura fue hegemónica durante muchos decenios pero comenzó a ser atacada por algunos historiadores, que señalaron las fisuras que presentaba la idea de un rabinismo tempranamente triunfante. Si bien, como veremos, ya el propio Goodenough (entre otros) tensionó la noción de una inmediata hegemonía rabínica, autores como Shaye Cohen (1981) o Seth Schwartz (2001) desarrollaron con más precisión la idea de un crecimiento gradual del grupo rabínico. Schwartz fue acaso quien llevó más lejos la crítica, pues constituyó un relato en el que el judaísmo rabínico ocupó sólo un lugar marginal en el escenario palestinense hasta el siglo IV y, sólo a partir de allí, comenzó a ganar visibilidad hasta erigirse como el grupo hegemónico. En una línea similar, Hayim Lapin (2011) sostuvo que la elite rabínica debía ser entendida como un grupo minoritario hasta el IV y hegemónico recién a partir del VI. Otros autores también remarcaron la lentitud del proceso de rabinización y pusieron la lupa en la existencia de colectivos que también reclamaban la herencia del judaísmo, cuyos textos se han perdido pero que son mencionados, en ocasiones, por los propios rabinos. ${ }^{14} \mathrm{El}$ sacerdocio jerosolimitano fue, como veremos luego, rehabilitado en estas nuevas lecturas que, con buen tino y siguiendo a Martin Goodman, dudaban de que la multiplicidad que presentaba en el judaísmo antes de la caída del Segundo Templo se hubiera evaporado en unos pocos decenios. ${ }^{15}$

Las posiciones sobre cómo se desarrolló el movimiento rabínico quedaron, entonces, divididas, a grandes rasgos, en dos campos: maximalistas y minimalistas. El problema también se asocia a la ponderación que cada grupo realiza de las fuentes disponibles. Los minimalistas hacen foco principalmente en la evidencia de tipo arqueológica y epigráfica en la que lo rabínico está ausente o, cuanto menos, difuminado, mientras que los maximalistas dan más lugar a la propia evidencia rabínica.

Por nuestra parte, tendemos a alinearnos en la corriente minimalista, dado que hacer descansar nuestros conocimientos sobre el/los judaísmo/s de la Tierra de Israel en los textos producidos por quienes se arrogaban el legado de la Torá y lo proyectaban incluso a temporalidades previas a su propia existencia es metodológicamente cuestionable. Es cierto que se ha avanzado en comprender cómo ciertos elementos artísticos, epigráficos y arqueológicos pueden ser interpretados en clave rabínica; ${ }^{16}$ no obstante, seguimos pensando que los contrastes son mayores que las coincidencias. Ante la ausencia de pruebas extra-rabínicas categóricas, nos permitimos dudar de la velocidad de la rabinización.

En resumen, consideramos que la perspectiva minimalista (aunque sin ser llevada al extremo) ofrece mayores posibilidades explicativas del registro arqueológico y epigráfico, a la vez que permite contextualizar tanto la literatura rabínica como las menciones al judaísmo por parte de autores cristianos de la 
región. En lo que a nuestro trabajo respecta, si aceptamos que la rabinización en la propia Palestina fue lenta es más fácil comprender por qué las comunidades judías europeas no manifiestan, en temporalidades tempranas, señales claras de rabinización. ${ }^{17}$ Somos conscientes de que tales indicios tampoco son fáciles de detectar -más allá de la producción literaria-en el propio territorio de Palestina, aunque es menester afirmar que, aunque escasas, las evidencias (literarias, epigráficas y arqueológicas) colectadas en la Tierra de Israel sí dan cuenta de algunos aspectos vinculados a la rabinización, mientras que en la Diáspora tales señales sólo aparecen muy tardíamente. Veamos, ahora sí, el derrotero que ha seguido la noción de un judaísmo no rabínico guiándonos por los pioneros aportes de Erwin Goodenough.

\section{Erwin Goodenough y el judaísmo no-rabínico}

Como bien señala Steven Fine $(2005 \text {, p. } 36)^{18}$ en su brillante resumen sobre el derrotero historiográfico del estudio del judaísmo tardoantiguo, fue Ludwig Blau, en la década de 1920, quien primero llamó la atención sobre ciertas disonancias entre la literatura rabínica y los registros arqueológicos y epigráficos. En efecto, Blau (1924 y 1926) disponía ya de una panoplia de restos epigráficos y arqueológicos judíos que podía esgrimir como prueba. Así, con mucha sutileza $\mathrm{y}$ en el marco de dos reseñabibliográficas, mostraba aquello que observaba como inconsistencias entre el discurso rabínico y ciertas representaciones e inscripciones halladas en las catacumbas judías de Roma, en sinagogas como Hammam Lif (norte de frica), Capernaum o Corazín (ambas en la Tierra de Israel). Si bien sus planteos fueron moderados, el final de su artículo de 1924 terminaba de modo bastante enfático:

Jewish life especially still furnishes information for the understanding of Early Christianity, because popular Judaism, which influenced Early Christianity the most, is not contained in the Talmud, and still continues its existence in the present to a certain extent, and there exist even today Jewish customs, usages, prayers, and the like which are older than the Talmud, and perhaps even than the Bible (Blau, 1924, p. 23).

Nótese, volveremos sobre esto, la noción de judaismo popular que tomará el primer Goodenough y generará tanto rechazo en la crítica. Ahora bien, los planteos de Blau no hicieron mella en la historiografía y posiciones tradicionales como las de Samuel Krauss, Louis Ginzberg y George Foot Moore -que no veían en la realidad material de Palestina o la Diáspora elementos alógenos al rabinismo- continuaron siendo poco cuestionadas.

Aparece, en ese contexto, Jewish Symbols in the Greco-Roman Period, cuyo primer volumen fue publicado en 1953. ${ }^{19}$ Allí Erwin Goodenough sostuvo explícitamente que el grupo rabínico no fue el único judaísmo superviviente tras la caída del Segundo Templo en el 70 e.c. Así, según su perspectiva, gran parte del arte tardoantiguo no sólo no se ajustaba a los patrones rabínicos sino que respondía a una corriente judía distinta y contemporánea. En sus palabras:

If we cannot here go into the problem of the attitude of the rabbis to images, let me beg the question for the moment and say that the art seems to me definitely a part of Judaism, but to have no real place in rabbinic Judaism. By that token it would fall into 
what is generally called Hellenistic Judaism. Hellenistic Judaism, if my hypothesis is right, is altogether too important a movement for us to scamp the slightest evidence which might illuminate it. Both the later mystic movements in Judaism, and the hellenization of Christianity, seem to me to have flowed out from this largely hidden source (Goodenough, 1953, pp. 22-23).

La producción de Goodenough era, en cierto punto, el resultado del impacto que generó en el mundo de los estudios judaicos el descubrimiento de un tipo de arte figurativo (sinagogal y funerario) que hizo estallar la noción previa del arte judío ${ }^{20}$ como esencialmente no figurativo. La excavación de la sinagoga de Beit Alfa en 1929 y el desenterramiento de la sinagoga de Dura Europos en 1932 pusieron al descubierto, en pisos y paredes, representaciones de individuos, signos del zodíaco, animales y todo un repertorio de imágenes que el rabinismo, según las lecturas de la literatura rabínica que se realizaban en la época, censuraba. ${ }^{21}$

Ante los hallazgos, los especialistas debían decir algo. Las opciones eran varias. ¿Los rabinos habían sido más flexibles de lo que se pensaba? ¿La praxis artística no se condecía con el discurso rabínico pero era aceptada? ¿La sinagoga no se encontraba bajo la órbita de aquellos? ¿Había rabinos abiertos a las innovaciones artísticas que no habían trascendido en el discurso? ¿O se había interpretado erróneamente la evidencia (rabínica) escrita?

Goodenough, como anticipamos, adoptó ciertas posiciones que marcaron el derrotero posterior del campo. Estas provenían no sólo del impacto que había generado el tipo de arte judío al que recién nos referimos, sino también de su propia experiencia en relación con sus conocimientos sobre Filón de Alejandría y el Nuevo Testamento. ${ }^{22}$ Había, en su perspectiva, un judaísmo no rabínico. Era una religiosidad que había permanecido en las representaciones artísticas. Un judaísmo que -ya en sus conclusiones, publicadas 12 años después del primer volumen y de agrias críticas- ${ }^{23}$ denominaba, casi con cariño, "Judaism of my symbols" (1965, v. 12, p. 190). De hecho, en tales conclusiones ya no rotulaba con tanta certeza como en el primer volumen: "I have no interest in deciding what we should call this Judaism of Philo and the symbols" (1965, v. 12, p. 190).

Para (re)crear tal judaísmo no-rabínico, Goodenough realizaba dos operaciones que ya adelantamos. Primero debía despejar la noción de un rabinismo totalizador:

(...) there is no evidence that Jews outside Palestine, or that any considerable proportion of the Jews even in Palestine itself, understood the Hebrew or Aramaic of the Schools, or that the Rabbis had any interest in making their Mishnah available to outsiders (1965, v. 12, p. 185).

La segunda operación consistía en tornar exógeno al rabinismo todo el conjunto de símbolos detectados en el registro arqueológico y atribuirlo a un tipo de judaísmo diferente que se asemejaba al reflejado en Filón (aunque no sólo en él, desde su perspectiva): ${ }^{24}$

The hellenized Jews were loyal to the People and the holy Writings, but they interpreted them more as did Philo (mind, I do not say just as did Philo) than in the way the rabbis are now recorderd as having done in Palestine and Babylonia. Such hellenized Judaism seem witnessed from Rome and Tunis to Mesopotamia (1965, v. 12, p. 197). 
La coexistencia entre judaísmo rabínico y judaísmo "helenístico" se reflejaba, también, en la Tierra de Israel:

The rabbis were composing the Gemarah at the same time when, and the same place where, Jews with Roman names were puting Helios and the Seassons in the synagogue, ${ }^{25}$ and commemorating their gifts in Greek inscriptions. We seem indeed presented with direct evidence that two quite different sorts of Judaism flourished in the same city, a phenomenon that offers no novelty to Jewish historians of any period (1965, v. 12, p. 186).

Dos judaísmos, entonces. El rabínico y otro (helenístico, místico, "de los símbolos", filoniano, popular, etc.). El planteo de Goodenough era lúcido aunque desde su formulación inicial fue puesta en tela de juicio, no sin razón, la rigidez en su análisis sobre la posición rabínica frente a las representaciones. Fue rechazado, también, el modo en el que asoció judaísmo helenístico a misticismo. ${ }^{26}$ Como veremos luego, el puente que trazó (aunque principalmente en los primeros volúmenes) entre el "judaísmo de sus símbolos" y lo popular también fue blanco de críticas.

El silencio de las fuentes judeo-europeas volvió a permitir que se impusiera sobre el continente la matriz de un judaísmo alógeno. Porque considerar que en la Roma del siglo V existió un judaísmo helenístico es caer, nuevamente, en la idea (por cierto, avalada e impulsada por las fuentes cristianas a través de la noción de un judaísmo testimonial y fosilizado) de comunidades estáticas que no tenían capacidad de reformular su legado y mutar con el tiempo. ${ }^{27}$ Goodenough vio judaísmo helenístico porque era una de las pocas vertientes no rabínicas que tenían voz propia.

Más allá de las críticas, creemos que un aspecto de su planteo fue (y es) fundamental: la idea de un judaísmo no rabínico. De hecho, la expansión del rabinismo, para Goodenough, sólo se habría impuesto a partir del siglo VI:

If, however, one should grant that, with all the corrections of detail which further study and discovery may reveal, such a widespread and deeply moving judaism actually existed, what then became of it? To this I must answer that from direct evidence we know nothing; but it would seem that the leaders of this Judaism from the sixth to the eight centuries had a great change of attitude. They learned Hebrew, after more than half a millenium when Hebrew had been a dead language for all but the learned even in Palestine. As they did so they could for the first time learn to pray in Hebrew, to read the scriptures in Hebrew, and to study the rabbinical writings (1965, v. 12, p. 198).

Nótese que, en estas conclusiones, Goodenough delinea una elite judía no rabínica que, desde el VI, se hebraíza y rabiniza. Insisto en la importancia de discutir la existencia de tal elite no-rabínica porque en general Goodenough fue atacado por considerar que el judaísmo de "sus símbolos" era popular y se oponía a una elite (rabínica). En efecto, la oposición cultura rabínica-cultura popular fue postulada inicialmente por Goodenough (recordemos que ya se vislumbraba en Blau) pero él mismo, con la sucesiva publicación de los tomos de Jewish Symbols, fue dándole forma, como hemos visto recién, a la idea de elites no judías. ${ }^{28}$ Sin embargo, tanto sus críticos de aquel momento como algunos de los actuales siguieron insistiendo en tal dicotomía postulada por el Goodenough inicial. ${ }^{29}$

Ahora bien, si para Palestina era, en algún punto, difícil sostener la idea de elites no rabínicas, en la Roma tardoantigua lo difícil era, al menos desde la epigrafía, 
justificar la existencia de una elite rabínica. En 1960 Harry Leon publicó un libro sobre los judíos de la Roma Antigua basado en la evidencia arqueológica, epigráfica y artística obtenida en las catacumbas de la Ciudad Eterna. Si bien no se planteó abiertamente la temática de la rabinización, dedicó unas importantes palabras a este debate cuando analizó las imágenes halladas en las catacumbas:

For my own part, I feel that to cite passages from the Talmud, as some scholars have done, can be of little value in helping us to a solution. The inscriptions have clearly demonstrated that there was little, if any, knowledge of Hebrew among the Jews of Imperial Rome, so that the opinions of the rabbis were probably quiet unknown to them (Leon, 1960, p. 226).

No obstante, con mucha lucidez, Leon dudaba -confrontando con Goodenough- de la utilidad de Filón al momento de recuperar la historia de los judíos de la ciudad de Roma:

Neither will quotations from Philo help us a great deal, since Philo's allegory and mysticism were far removed from the thought and experience of the comparatively uneducated Jews of the Roman community (Leon, 1960, p. 226).

Más allá de que la caracterización de la comunidad judía romana como poco educada pueda ser puesta en tela de juicio, las intuiciones de Leon sobre la dificultad de usar material de otras regiones para recomponer el cuadro del judaísmo de la ciudad siguen siendo válidas. ${ }^{30} \mathrm{El}$ autor también consideraba que ciertos especialistas - nuevamente, el más visible, Goodenough- habían exagerado con la interpretación mística del repertorio iconográfico hallado en sitios judíos y tendía a ser escéptico sobre nuestras posibilidades de comprender el mensaje que había intentado plasmarse allí.

Años más tarde Vittore Colorni -en un texto que ha sido sistemáticamente omitido pero es de gran trascendencia según nuestro punto de vista- retomó abiertamente la posición de Goodenough. Su punto de partida fue el análisis de la Novella 146 Пвpi Eßpai $\omega \nu$ (553 e.c.) de Justiniano, en la cual el emperador impelía a los colectivos judíos a aceptar la lectura de la Biblia en griego, latín o cualquier lengua. A su vez, prohibía la lectura de los textos que denominaba deuterosis, en posible referencia a la Mishná. Para Colorni este hecho ponía de manifiesto el avance del judaísmo oriental de corte rabínico sobre el helenístico, el cual, apelando a la ayuda del emperador (quien en la novella declara haber sido consultado por los propios judíos a causa de una disputa interna), intentaba refrenar la imposición del hebreo. Más allá de los debates sobre la norma y su significado, es interesante que Colorni extiende también su análisis a la epigrafía e intenta llegar a conclusiones amplias. Es pertinente, para no abundar con la paráfrasis, analizar secuencialmente algunos de los pasajes más significativos del autor sobre el tema que aquí nos compete:

I confini dei due mondi peraltro, quello degli ebrei di lingua e cultura greca e quello degli ebrei di lingua e cultura aramaica, restavano di regola, ad onta di tali eccezionali intrecci, ben distiniti e separati fra loro (Colorni, 1964, p. 12).

El autor, como ya había sugerido Goodenough, establecía una dicotomía clara entre regiones basada en el aspecto lingüístico, cuestión que llevarán aún más lejos Edrei y Mendels ya en el siglo XXI. Colorni empleaba, sin dudarlo, las categorías dispuestas por Goodenough: 
Effettivamente, anche senza espressioni letterarie, il giudaismo elenistico resta tale ancora per centinaia d'anni e soltanto con estrema gradualità si compiono il suo tramonto e la sua conquista da parte della tradizione del giudaismo aramaico (Colorni, 1964, p. 14).

Postula, entonces, la existencia de un judaísmo helenístico en todo Occidente aunque debe aceptar -lo dice al pasar- que no se poseen expresiones literarias de este judaísmo ante el cual, aventura, se erigió un nuevo judaísmo, de base aramea, que sólo lentamente se impuso y "conquistó" a ese otro judaísmo. Colorni, centrándose en sus lecturas epigráficas, afirma:

Il giudaismo, diciamo, occidentale (in contrapposto a quello babilonese) resta ellenistico o diviene ellenistico-latino. Ma l'ebraizzazione è ancora lontana. Lentissimamente però il tramonto si inizia (Colorni, 1964, p. 46).

Si bien tibiamente, el autor sugiere que los judíos europeos (y norafricanos) pudieron haberse latinizado. En otras palabras, abre las puertas al dinamismo, sacando a los judíos de la imagen de estáticos herederos del judaísmo que había vivido Filón varios siglos antes. Sobre la base del repertorio epigráfico, arqueológico y literario resume, en pocas líneas, las dificultades para conocer los pormenores del proceso de rabinización:

Le vicende di questa riebbraizzazione delle comunità giudeo-ellenistiche, che sepellisce nell'oblio più completo tutti i testi greci o latini in precedenza in uso presso di esse e trasforma il giudaismo dell'Africa, dell'Asia Minore e dell'Europa, a partire almeno dal IX secolo, in semplici propaggini del giudaismo babilonese, ci sono ignote (Colorni, 1964, pp. 49-50).

Para el siglo IX, decía Colorni, los judaísmos de Europa, Asia Menor y África perdieron su identidad y devinieron simples satélites del judaísmo babilónico. En el siglo IX -Colorni sigue apegado al registro epigráfico- el proceso ya se observa consolidado. El cambio gradual se daría (aunque las fuentes no permitían documentarlo claramente) entre los siglos V y VIII (Colorni, 1964, p. 50). ${ }^{31}$ Nótese que el autor se refiere, aunque gradual, a conquista, y cierra la puerta a formas mixtas.

Goodenough volvió a ser reivindicado abiertamente en 1981 a través de la epigrafía. En un artículo fundamental que ya hemos mencionado, Shaye Cohen consideró que los rabinos que aparecían en inscripciones (epigraphical rabbis) no eran, en realidad, rabinos. Según su perspectiva, el título de rabino era honorífico y no coincidía con aquellos sujetos que habían escrito la literatura canónica que llegó hasta nuestros días. Pero incluso si se aceptaba que los rabinos epigráficos eran aquellos rabinos del Talmud, la cantidad de registros que se habían hallado y su bajísima aparición en sinagogas demostraban que no tenían control sobre el judaísmo. El fenómeno, además, era más claro en la diáspora:

Thus Goodenough is vindicated: diaspora Jews in antiquity did not live under the spiritual hegemony of the land of Israel. Indeed, the burden of proof is not upon Goodenough but upon those who assert that the Jews of the "Rabbinic period" followed Rabbinic norms (Cohen, 1981, p. 16).

Lee Levine publicó varios estudios vitales sobre el grupo rabínico y su relación con la sinagoga (entre otros, 1989 [1985] y 2005 [2000]). Para el autor -resuenan aquí nuevamente los ecos de Goodenough-, el poder rabínico había sido limitado 
(2005, p. 472), al menos en lo que concernía a la sinagoga. ${ }^{32}$ Sugería, también, la existencia de un grupo no-rabínico que habría tenido cierto control sobre las casas de culto: el grupo sacerdotal. Postulando ello -aunque siempre con moderación-, Levine reemplazaba, al menos para Palestina, la voz rabínica por la voz sacerdotal. Esto se reflejaba, siempre según el autor (2005, pp. 519-529), no sólo en el rol de benefactores sinagogales sino también en la ostentación de cargos en tal institución. ${ }^{33}$ En lo que respecta a la Diáspora, fue cauteloso. Si bien se refiere a sacerdotes en algunas sinagogas como Sardes o Dura Europos no extiende, al menos no abiertamente, la idea de poder sacerdotal a la Diáspora y se limita a analizar los cargos que aparecen en la epigrafía sin expresar conclusiones categóricas sobre qué tipo de judaísmo existía en las sinagogas más allá de la Tierra de Israel.

Frente a quienes postulaban la idea de judaísmos rabínicos y no rabínicos disímiles, vale recuperar -con el fin de ilustrar que el campo siempre estuvo dividido- la voz de Leonard Rutgers quien, en 1998, no sólo instó a no exagerar las diferencias regionales entre judaísmos sino que también consideró que el rabinismo había sido probablemente aceptado de buena gana y con relativa rapidez en las diásporas occidentales:

Still, the larger Jewish communities in the Diaspora must have been acutely aware of the developments in Roman Palestine. Even though we really do not know who are the rabbis referred to in several late antique inscriptions from the western Diaspora, Diaspora communities may very well have reacted congenially to these developments. Considering that these Diaspora communities had much in common when it came to upholding the Jewish tradition, it is conceivable that they welcomed rabbinic Judaism as a new yet genuine expression of Judaism, especially in a period when the original tension between the rabbis and the rest of the Jewish population had begun to give way to a more cordial and constructive relationship [...] In conclusion, it must be said that it would be absurd to argue that all the Jewish communities of the Mediterranean were completely identical in terms of practices and belief, or that these beliefs and local minhagim remained constant over time. I believe that a fresh look on archaeological and epigraphic materials suggests, however, that despite such local differences, Jews in many part of the ancient world may very well have agreed on a number of issues (Rutgers 1998, 27-28).

Rutgers (1998, p. 27) databa el comienzo de la influencia rabínica en la Diáspora hacia el IV y consideraba que el alto grado de homogeneidad y conectividad entre los grupos diaspóricos que observaba podría explicar -lo afirmaba en condicional- el modo en el que el rabinismo progresó más allá de Palestina desde tal siglo. Es pertinente recordar que el autor sí aceptaba la lentitud del avance rabínico en la propia Tierra de Israel hasta el siglo IV y daba lugar, haciéndose eco de Levine, a la persistencia de otros grupos, como el sacerdotal (Rutgers, 1999).

Volviendo a la senda de quienes consideraban la existencia de judaísmos claramente diferentes, el siguiente hito proviene de la pluma de un autor que ya mencionamos, Seth Schwartz (2002). Ante todo, como lo indica su título, consideró al siglo VI como el momento de rabinización de la Diáspora. Por otra parte, comenzó su artículo por el tiempo medieval para recordarnos, como ya anticipamos, la existencia de costumbres que no estaban atadas, al menos en su origen, al ideario rabínico. 
I think it worth suggesting that rabbinic norms have always been in tension with other norms, many of them marked as Jewish, and called in the Middle Ages minhag. Rather than looking for a rabbinic victory, it is this tension, caused by the introduction of rabbinic Judaism into the larger social system of Judaism, that we should be seeking (Schwartz, 2002, p. 55).

Aquí Schwartz se opone a la idea de una rabinización total (aunque tardía), como había sugerido Goodenough, y, más directamente, a la noción de conquista que habían constituido autores como Colorni. ${ }^{34}$ Si bien seguimos en el plano de un judaísmo al cual se le adosa otro judaísmo, la idea de Schwartz apunta más, en todo caso, a la yuxtaposición y a la tensión generada por la supervivencia de tradiciones múltiples, visibles aún en el Medioevo y aglutinadas bajo el término minag. La persistencia de costumbres que parecen provenir de un tiempo prerabínico y en ocasiones colisionan contra los postulados de los rabinos no había sido iluminada por Goodenough quien, como anticipamos, optaba más por la idea de reemplazo. El estudio de tales minaguim en temporalidades posteriores al primer milenio representa, desde nuestro punto de vista, una veta muy importante, que puede aportar elementos para comprender el judaísmo prerabínico. ${ }^{35}$

En 2005 Goodenough vuelve a la palestra. En este caso Jodi Magness, en la senda de Levine, afirmaba:

I suggest that Goodenough's interpretation was closer to the target: the images that decorate ancient Palestinian synagogues should be understood in relation to a mystical and nonrabbinic form (or forms) of Judaism (Magness, 2005, p. 2).

Pero a diferencia de Goodenough, la arqueóloga veía en los zodíacos de las sinagogas de Palestina la plasmación de un tipo de judaísmo místico de corte sacerdotal:

Instead, I attempt to remove the consideration of the iconography of these mosaics from the traditional rabbino-centric perspective, and to argue that they provide evidence for the interests of at least one more influential Jewish group in late ancient Palestine - the priestly class (Magness, 2005, n. 5, p. 2).

Donde Goodenough había puesto la voz de Filón, Magness - siguiendo la línea de Levine- insertó las voces de la literatura Hejalot que, según su lógica, evidenciarían la supervivencia de la clase sacerdotal. Un judaísmo sacerdotal que, como reflejo a la construcción de iglesias, erigía sinagogas donde se proyectaba el Gran Templo y se filtraba el misticismo de la tradición Merkavá (2005, p. 14). Nótese que, a diferencia de lo sostenido por otros autores, el crecimiento de la sinagoga y del espacio reservado a la Torá no se asociaría a un proceso de rabinización sino más bien a una respuesta al cristianismo por parte de grupos no rabínicos. $^{36}$

Lamentablemente, Magness no establecía conclusiones sobre la Diáspora aunque, en una nota al pie, dejó entrever que el poder sacerdotal podría explicar también aspectos comunitarios fuera de la Tierra de Israel. ${ }^{37}$

En 2007 y 2008 Arye Edrei y Doron Mendels escribieron dos artículos que aspiraban a revolucionar las ideas previas en torno a las diásporas tardoantiguas. En realidad, lo que hicieron fue llevar al paroxismo -si bien con gran inteligencianociones que ya habían esbozado otros autores, entre ellos Goodenough y Colorni. ${ }^{38}$ Debe reconocérseles, no obstante, que sus artículos $-\mathrm{y}$ el posterior 
libro del cual hablaremos en breve- poseen ideas interesantes (algunas de ellas disruptivas, aunque no acordemos) y, cuanto menos, contribuyeron a reavivar el debate sobre las “diásporas partidas". El resumen de su trabajo expone claramente sus ideas:

This article proposes that a language divide and two systems of communication have brought to a serious gap between the western Jewish Diaspora and the eastern one. Thus the western Greek-speaking Jews lost touch with the Halakhah and the Rabbis, a condition that had far-reaching consequences on Jewish history thereafter. The Rabbis paid a high price for keeping their Halakhah in oral form, losing in consequence half of their constituency. An oral law did not develop in the western diaspora, whereas the existing eastern one was not translated into Greek. Hence it is not surprising that western Jews contributed nothing to the development of the oral law in the east. The Jewish communities that were isolated from the Rabbinic network served as a receptive basis for the development of an alternative Christian network by Paul and the apostles, which enabled it to spread throughout the Mediterranean basin. The Jews that remained 'biblical' surfaced in Europe in the Middle Ages (Edrei-Mendels, 2007, p. 91).

Tal como señalarán diversos investigadores e investigadoras, la partición lingüística realizada por Edrei y Mendels es, sin dudas, extrema. Olvida que en la propia Palestina el griego era una lengua conocida por una parte importante de los rabinos. Deja a un lado, también, los indicios que, aunque escasos, dan cuenta de cierto nivel de interacción entre los colectivos de Oriente y Occidente. Por otra parte, la existencia de dos campos definidos, sin gradaciones ni particularidades regionales, abrió también espacio a la crítica, lo que llevó a los autores -en su libro aparecido apenas años después- a enfatizar que Egipto y Siria fueron espacialidades de influencia rabínica moderada. ${ }^{39}$

Más grave, desde nuestro punto de vista, es la noción de la existencia de judíos "bíblicos" en Europa. ¿A qué se refieren los autores cuando utilizan esta categoría?: "While in the east, a new normative standard, the Oral Law, developed, in the west, the Jewish communities remained biblical, maintaining the tradition as it existed before the rise of the Rabbis and their teachings" (2007, p. 114). Así, incluían subrepticiamente dos postulados problemáticos. El primero, como ya señalamos en los planteos de Goodenough, es negar, a los colectivos europeos tardoantiguos, la posibilidad de mutar con el tiempo. El segundo, íntimamente asociado, es considerar que -dado que no ha llegado nada a nuestros tiempos- no hubo producción escrita judía más allá de la propia Biblia (por cierto, tampoco llegaron "biblias judías" del período y nadie dudaría de que los judíos las utilizaron). ${ }^{40}$ Por supuesto, insistimos, no es posible explicar fácilmente la no supervivencia de producción escrita, pero sería verdaderamente extraño que los judíos europeos no hayan producido material. Considerar que los judíos europeos se quedaron simplemente con la Biblia y fueron pasivos receptores del mensaje cristiano es, insistimos, una petición de principio nacida de un silencio que es más nuestro que de ellos. Es más, Edrei y Mendels utilizan los textos cristianos para demostrar, en su lógica, que no hay rastros de rabinismo y que los judíos eran un colectivo estático. De este modo, terminan aceptando el discurso adversus Iudaeos y -consciente o inconscientemente- observando a los judíos desde el prisma agustiniano de los testes Veritatis, fósiles vivientes de la verdad cristiana. 
Estos debates cristalizaron, en 2010, en un libro donde los autores resumen sus posiciones: Zweierlei Diaspora. Zur Spaltung der antiken Jüdischen Welt. Dado que no hay en la obra aportes que excedan lo publicado en los dos artículos previos, más allá de cierta matización de sus conclusiones más extremas, no es necesario abundar en ella. ${ }^{41}$ Sólo queremos agregar que en el libro se confirma otra tendencia de los autores: ver el desarrollo rabínico en Palestina desde un prisma maximalista, mientras que los avances rabínicos en Occidente son juzgados desde una perspectiva minimalista. ${ }^{42}$

En 2013 sale a la luz otra ambiciosa obra, elaborada por Anna Collar: Religious Networks in the Roman Empire. Desde una perspectiva sociológica centrada en el estudio de redes, dedica un capítulo a lo que denomina reformas rabínicas en la Diáspora judía occidental, en las antípodas del planteo de Goodenough y, más explícitamente, de Edrei y Mendels. El capítulo es ambicioso y presenta bastantes puntos débiles. No obstante, hace un inteligente uso del material y algunas de sus conclusiones son válidas o, cuanto menos, discutibles.

Collar considera, en primer lugar, que los judíos que habitaron la Diáspora occidental antes de la caída del Segundo Templo no sentían la necesidad de visibilizar su identidad dado que su centro de referencia, Palestina, estaba activo y era dinámico. Tenemos, aquí, dos problemas. En primer lugar, la exacerbación del esquema centro-periferia; esquema que deja a las diásporas siempre en un lugar marginal y cercena las posibilidades de que las comunidades judías fuera de Palestina se sintieran su propio centro de gravedad. En efecto, es al menos discutible que los judíos alejandrinos (cuyos textos sí conocemos) se hayan percibido en el margen y la propia constitución de la LXX es muestra patente del orgullo por el suelo habitado (Laham Cohen, 2019). ${ }^{43}$ En segundo término, otra vez, las fuentes. ¿Es la ausencia de restos epigráficos calificables como judíos un marcador claro de ausencia de judíos o de falta de interés por remarcar la identidad mosaica? El caso alejandrino vuelve a poner en tensión estos aspectos. No se han hallado más de veinte lápidas reconocibles como judías en una ciudad que -aquí hay consenso historiográfico- concentró a decenas de miles de judíos. O sea, presencia judía sin testimonio epigráfico. Y, por otra parte, los textos de Filón que nos marcan con claridad que al menos un grupo de judíos sí sentía la necesidad de reafirmar su identidad mediante obras literarias y celebraciones específicas, como la fiesta anual realizada en la isla de Faros en recuerdo de la traducción de la Septuaginta.

Pero incluso si se concede la idea de que los judíos de la Diáspora occidental no sentían la necesidad de atestiguar su identidad en la epigrafía, la autora realiza otra operación cuanto menos cuestionable: considera que los marcadores de rabinización no son sólo las referencias a rabinos, las citas talmúdicas o el uso del hebreo, sino también la utilización de iconografía como la Menorá o, incluso, la mera mención del carácter judío del difunto. Este aspecto la lleva a considerar la existencia de una rabinización temprana en la región. Así, al remontar la rabinización de la Diáspora hasta el siglo II (haciendo caso omiso de las posturas que han demostrado, siempre a nuestro criterio, la lentitud de la rabinización en el propio territorio de Palestina), critica también posiciones como las de Boyarin, Schwartz o Magness, quienes vieron en el ascenso del cristianismo la causa del aumento de marcadores identitarios por parte de los judíos, tanto de la Tierra de Israel como de la Diáspora. 
Por supuesto, para referirse a una rabinización temprana Collar se ve obligada a disputar con Edrei y Mendels respecto de la comunicación entre ambas regiones. ${ }^{44}$ Allí, con buen tino, marca las limitaciones de la aproximación de los mencionados autores, quienes, como vimos, presentan un modelo extremadamente rígido basado en lo lingüístico. Esgrime, así, algunos elementos que darían cuenta de comunicaciones tempranas. Claro que Collar va, desde nuestro punto de vista, al otro extremo, sobrevalorando evidencias que hablan de contactos pero no de rabinización. Debe reconocérsele, sin embargo, que su embate contra Edrei y Mendels es para tener en cuenta, al menos en lo que respecta a temporalidades no tan tempranas, y valga de ejemplo el trato que dispensa a los apostoli atestiguados en el Código Teodosiano hacia el siglo $\mathrm{V}$ y a la Novella 146 de Justiniano del VI.

A diferencia de la mayoría de los autores, para Collar fue precisamente la caída del Segundo Templo la que acercó y, en algún punto rehabilitó, el eje Este-Oeste. En este punto, y en virtud de la evidencia, nos sentimos más cerca de los planteos del resto de los autores -incluso de Edrei y Mendels-, dado que la evidencia que usa Collar para referirse a los contactos entre Occidente y Oriente es, como mínimo, débil. ${ }^{45}$ Sí reconocemos, no obstante, un aporte: al enfatizar los rastros de contacto nos pone en guardia sobre nociones extremas de aislamiento. ${ }^{46}$ Porque si bien entendemos que los judaísmos de Europa tuvieron sus especificidades, más ligadas a su contexto local que a la influencia de Oriente, es demasiado radical ( $\mathrm{y}$ contra las evidencias) afirmar que ninguna noticia o idea de Oriente pudo llegar, incluso impactar, en Europa (y de modo diverso según la región).

Resumiendo, los problemas del planteo de Collar son básicamente dos: asocia la aparición de más marcadores identitarios a rabinización y, por otra parte, sobrevalora tales marcadores identitarios, escasísimos en los primeros dos siglos de la Era Común y bastante dispersos hasta, al menos, el siglo VI. Leamos sus palabras:

It is abundantly clear that the epigraphy undergoes a major change from the third century onwards, with an enormous increase in Jewish self-identification, manifest in the use of Jewish names, terms, symbols and Hebrew. This can only be adequately explained as the epigraphic reflection of the accurate, doctrinal transmission of the rabbinic reforms to the ordinary people of the Diaspora, as visual evidence for the gradual spread of universalizing halakah (Collar, 2013, p. 195).

En cuanto a la asociación mecánica entre self-identification y rabinismo, plasmada, por ejemplo, en la idea del vínculo entre representación de la Menorá y el mundo rabínico, hay allí una petición de principio: que los judíos de Europa no pudieron haber decidido ellos mismos que la Menorá (aquella que los que habitaban en Roma veían muy seguido en el Arco de Tito) fuera su símbolo identitario primario. En cuanto al enormous increase de los marcadores identitarios, la autora confunde (y adelanta), insistimos, el proceso que Schwartz llamó rejudaización con el de rabinización.

Llegamos ahora a un texto publicado recientemente por Johannes Heil (2017). Se trata de un artículo osado, polémico y, en algún punto, experimental, que contiene, sin embargo, intuiciones valiosas que, como aclararemos luego, van en una dirección que consideramos correcta. Tal como anuncia el título de su trabajo, Heil aspira a reconstruir la historia del judaísmo hispano tardoantiguo 
desde una perspectiva diferente. Se centra, para ello, no en los típicos estudios sobre las conversiones de Sisebuto, los extractos de las leyes visigodas o los textos de Isidoro de Sevilla, sino más bien (y sorpresivamente) en un texto bastante oscuro denominado Liber Antiquitatum Biblicarum. Este texto anónimo que, por sus características, fue asociado a Filón es -junto con la Epistola Anne ad Senecam y a la Collatio legum Romanarum et Mosaicarum - uno de los tres textos cuyos autores han sido relacionados con el judaísmo. En el caso de la Epistola (que en realidad es un tratado) y de la Collatio, han existido voces tanto en dirección de una autoría cristiana como judía. El caso del Liber, aunque el carácter judío parece indudable, es complicado. En general se ha sostenido que el texto latino que hoy poseemos es una traducción de un original griego que, a su vez, habría tenido un antecedente hebreo. Heil, sin embargo, considera que no hay pruebas suficientes para sostener tal genealogía. Desde su perspectiva, el texto fue originalmente producido en Europa occidental (Hispania / sur de Galia) y representa una parte de la cultura judía -específica y no rabinizada- de la región. En sus palabras:

Das mag eine kleine Elite gebildeter Juden gewesen sein, die weit länger als im Osten auch noch Philo als jüdischen Autor rezipieren konnte und diesem dann selbst vielleicht irgendwann auch noch einen Pseudo-Philo beigegeben hat. All das ändert nichts am Befund, dass die Frage nach der Genese solcher Texte kaum eine andere plausible Erklärung als das Herkommen aus einer Latein lesenden judeo-romanischen Gesellschaft in Spanien und im Süden Frankreichs zulässt. Del Valles ,autochthone“ jüdische Kultur wäre dann doch kein pures Konstrukt, aber sprachlich eben ein Teil der romanischen Kultur seiner Umgebung. Und Wasserstein darf dann eben mehr als nur kulturelle Verarmung konstatieren (Heil, 2017, pp. 60-61). ${ }^{47}$

No ingresaremos aquí en el detalle sobre el origen del Liber y las estrategias de Heil para reubicarlo temporal y geográficamente. Pero sí rescatamos el objetivo del autor, quien, con claridad meridiana, afirma:

\begin{abstract}
Anstatt die westmediterrane jüdische Geschichte immer nur vom Osten her zu denken und geradezu verbissen an den wenigen, dünnen Fäden des Einflusses des Patriarchen auf die Gemeinden im Westen festzuhalten, erscheint es angemessener und auch ertragreicher, die westmediterrane jüdische Kultur als selbstständigen Teil und diesen vornehmlich im Zusammenhang ihrer umgebenden römischen und griechischen Kulturen unter den politischen und sozialen Bedingungen der barbarischen" Nachfolgereiche des weströmischen Reichs zu verstehen (Heil, 2017, p. 61).
\end{abstract}

Radica, aquí, una dirección correcta por la cual se debe mover, desde nuestro criterio, la investigación. No debemos buscar, siempre, la explicación rabínica o externa a lo que sucede en el judaísmo occidental. Es probable que Goodenough haya ido muy lejos en separar tajantemente lo rabínico de lo no rabínico y haya olvidado, en el mismo gesto, las disonancias al interior de cada grupo. No obstante, su legado en torno a la falta de homogeneidad del judaísmo tardoantiguo sigue, desde nuestra perspectiva, vigente.

\title{
Judaísmo europeo tardoantiguo: ¿qué y dónde buscar?
}

No presentaremos aquí una respuesta categórica a estos interrogantes, pero intentaremos esbozar cuáles creemos que son los caminos más adecuados 
para resolver la cuestión del judaísmo europeo tardoantiguo. En cuanto a qué buscar, la respuesta se construye en dos andariveles. En primer lugar, debemos tratar de comprender el funcionamiento de las comunidades judías prerabínicas a partir de evidencias locales. Es menester dejar de rastrear similitudes con el mundo rabínico. Ya el mero hecho de que aquí las hayamos denominado pre-rabínicas condiciona nuestra mirada. Pero más allá de la nomenclatura, debemos tratar de comprender a esos colectivos en su propio contexto, quitándonos los lentes rabínicos que tiñen toda la mirada de la Antigüedad Tardía judía. Esto no implica que nos neguemos a las comparaciones o a detectar posibles influencias (que deberían ser medidas en ambas direcciones) pero sí prescindir, al menos en las primeras aproximaciones al objeto de estudio, de preconcepciones surgidas en los espacios palestino y mesopotámico. Debemos evitar también la tentación de apelar a voces judías no europeas que operen como deus ex machina, ya sea bajo la forma de Filón y el judaísmo helenístico, como ha hecho Goodenough, o del sacerdocio jerosolimitano, tal como se ha planteado en tiempos más recientes. Ciertamente, el judaísmo europeo tardoantiguo no surgió por generación espontánea y tiene antecedentes e influencias de judaísmos alógenos. Pero debemos permitirnos pensar cada judaísmo como un movimiento con voz propia y capacidad de mutación producto de la interacción con sus contextos cercanos, tanto judíos como no judíos.

La segunda parte del qué buscar se asocia a detectar el momento en el cual la rabinización comenzó en la Diáspora europea. Pero la pregunta debe ser más compleja. Así como el dicho reza que una golondrina no hace verano, la presencia de una inscripción que mencione a un rabino no implica la completa rabinización de esa localidad y mucho menos de esa región. Pero la detección de un rabino epigráfico o de una cita talmúdica sí expresa con claridad que al menos en ese sitio una porción de la población tuvo contacto con parte del ideario rabínico. Entonces, deberíamos preguntarnos no acerca del momento preciso de rabinización sino sobre los primeros indicios de esta y el ritmo que pudo tener en cada localidad y región. Es claro que el sur de Italia, hacia el siglo IX, tenía una gran parte de la población rabinizada, lo que no sólo se verifica por un registro epigráfico altamente hebraizado con presencia de citas talmúdicas, sino también con la existencia de autores que escribieron en hebreo. Pero no es claro qué sucedió entre los siglos V y VIII. E insistimos en que no debe perderse de vista que en ciudades de una misma región -Venosa y Roma, para dar un ejemplo- los procesos pudieron haber sido independientes.

No debemos olvidar, tampoco, que estos judaísmos rabinizados pudieron, como anticipamos, haber conservado prácticas del período anterior. En tal sentido, no hay que imaginar la irradiación rabínica en términos de conquista o imposición total sino más bien de influencia y coexistencia (incluso tensa). Vale también adoptar la cautela de Hezser quien, si bien para Palestina, puso en duda la existencia de diferencias radicales entre grupos rabínicos y no rabínicos. Esto no implica que nosotros no creamos que hubo contrastes, pero es claro que ambos grupos (y sus respectivos subgrupos) compartían ideas, prácticas y tradiciones.

El cómo buscar es más difícil de responder porque no sólo implica lidiar con un conjunto de fuentes que, aunque escaso, es variopinto, sino también aceptar que los silencios documentales sesgan nuestra mirada y deben ser interpretados con sumo cuidado. En línea con lo afirmado en el québuscar, la literatura rabínica 
debe ser relegada a un segundo plano, al menos en el principio de la investigación. No nos referimos sólo a poner en cuestión las grandilocuentes declaraciones rabínicas sobre viajes a la Diáspora occidental, o directamente la presencia de academias rabínicas en Roma, sino también a su uso para encontrar, por ejemplo, puntos de contacto entre el archisinagogo epigráfico y el Rosh ha-Kneset literario. Hablamos de poner en segundo plano porque no estamos considerando que no deba utilizarse la literatura rabínica sino que sólo debe emplearse luego de haber agotado las posibilidades que el resto de las fuentes, incluso (y sobre todo) las nojudías, ofrecen. Porque no debemos perder de vista -insistimos en esto por última vez- que los rabinos, más que describir una sociedad, presentaron el modelo de cómo la deseaban y buscaron, para ello, mostrarse como los únicos (e incluso los más antiguos) intérpretes de la verdad bíblica.

Así las cosas, son las inscripciones, los edificios y las representaciones artísticas judías de Europa las que deben estar en el centro de nuestra reconstrucción del judaísmo europeo tardoantiguo. Deben ser pensadas no en relación con el mundo rabínico o alejandrino sino, más bien, con los propios espacios donde fueron halladas. Nos dice más sobre la comunidad judía de Ostia la similitud de su sinagoga con otros edificios locales que un intento de comparación con un pasaje de la Mishná. Nos explica más la utilización del término "gerusiarca" por un grupo politeísta de la ciudad donde fue hallada la inscripción que la asimilación acrítica a un cargo similar registrado en el Yerushalmi. La existencia de niños arcontes en los epitafios judíos se comprende mejor cuando se comparan con los niños curiales en las inscripciones funerarias itálicas no-judías. En lugar de pensar que los judíos nunca pudieron haber aceptado una representación de la diosa Victoria o que lo hicieron en clave filoniana, es mejor pensar por qué, como mínimo, no borraron tal imagen que se replica en los hipogeos paganos del lugar. O sea, tratar de entender a los judíos y a las judías de una ciudad en relación con los no judíos y no judías de ella. Por supuesto que el siguiente paso es ver las conexiones con otros colectivos judíos cercanos, dado que, como ya mencionamos, existen patrones regionales e, incluso, suprarregionales. Y, recién allí, avanzar en la dirección del mundo rabínico para corroborar similitudes y diferencias.

Hay que tener cuidado, también, con los marcadores que se utilizan para establecer en qué momento aquel judaísmo nacido en Oriente llegó a Europa. ¿Por qué el uso de una Menorá implicaría rabinización? ¿Por qué la expansión del sitio reservado para la Torá es considerado un síntoma de mayor rabinismo? Por supuesto que las decisiones serán, en algún punto, arbitrarias. Pero, cuanto menos, deben ser sustentadas. El único modo de corroborar la rabinización es, desde nuestra perspectiva, la detección de fragmentos de la literatura producida por los rabinos de Palestina y Babilonia en epigrafía (o, luego, en la propia producción literaria) de Europa. El avance del hebreo también puede ser asociado, aunque con algo menos de seguridad, con la imposición del judaísmo oriental. Ciertamente, la referencia al título rabino, aunque pueda ser debatida, si aparece en una cantidad importante ya da cuenta de la llegada del cargo a las comunidades occidentales. La onomástica es un marcador más ambiguo: después de todo, los cristianos también comenzaron a usar nombres bíblicos o de santos por el mero hecho de remarcar su identidad. Que un judío venosino del siglo 
V adopte el nombre Isaac no implica mecánicamente rabinización sino, en todo caso, una enfatización de su identidad judía.

Gran parte de los marcadores son, entonces, ambiguos. Y el problema, nuevamente, no se da en los primeros siglos, para los cuales, excepto la lectura de Collar, hay consenso sobre la lentitud del avance rabínico en la Diáspora occidental. El inconveniente se da, principalmente, entre los siglos V y VIII, en los cuales podemos advertir cierto avance del hebreo, por ejemplo, sin poder mensurar si ese marcador refiere a rabinización efectiva o, en caso de aceptarla, con qué magnitud y cómo coexistió con la forma previa de judaísmo. En relación con el arte, es aún más difícil establecer qué es rabínico y qué no es rabínico, porque, como advertimos, ni siquiera este aspecto es claro en la propia Tierra de Israel.

En resumen, el análisis del judaísmo de Europa durante la Antigüedad Tardía implica, como todo objeto de estudio, tomar decisiones en torno a qué fuentes ponderar y cómo analizarlas. Pero requiere, sobre todo, evitar imponer voces ajenas -sean estas de Alejandría, Jerusalén o Pumbedita- sobre aquellos judíos y judías. Porque, aunque silencioso, el judaísmo europeo tardoantiguo tiene derecho a ser investigado en sus propios términos.

\section{Referencias}

Baumgarten, J. (1999 [1970]). Art in the Synagogue: Some Talmudic Views. En S. Fine (ed.), Jews, Christians, and Polytheist in the Ancient Synagogue. Cultural Interaction during the Greco-Roman Period (pp. 62-76). Londres: Routledge.

Bickerman, E. (1965). Symbolism in the Dura Synagogue. Harvard Theological Review, $58,127-151$.

Blau, L. (1924). Early Christian Epigraphy from the Jewish Point of View. Hebrew Union College Annual, 1, 221-237.

Blau, L. (1926). Early Christian Archaeology from the Jewish Point of View. Hebrew Union College Annual, 3, 157-214.

Cappelletti, S. (2006). The Jewish Community of Rome. From the Second Century B.C. to the Third Century C.E. Leiden:Brill.

Cohen, J. (1999). Living Letters of the Law: Ideas of the Jew in Medieval Christianity. Berkeley: University of California Press.

Cohen, S. (1981). Epigraphical Rabbis. The Jewish Quarterly Review, 72(1), 1-17.

Colafemmina, C. (2000). Hebrew Inscriptions of the Early Medieval Period in Southern Italy. En B. Garvin y B. Cooperman (eds.), The Jews of Italy. Memory and Identity (pp. 65-81). Bethesda: University Press of Maryland.

Collar, A. (2013). Religious Networks in the Roman Empire: The Spread of New Ideas. Cambridge: Cambridge University Press.

Colorni, V. (1964). L'uso del greco nella liturgia del giudaismo elenistico e la novella 146 di Giustiniano. Milán: Giuffre.

Edrei, A. y Mendels, D. (2007). A Split Jewish Diaspora: Its Dramatic Consequences. Journal for the study of the Pseudepigrapha, 16(2), 91-137.

Edrei, A. y Mendels, D. (2008). A Split Jewish Diaspora: Its Dramatic Consequences II. Journal for the study of the Pseudepigrapha, 17(3), 163-187.

Edrei, A. y Mendels, D. (2010). Zweierlei Diaspora. Zur Spaltung der antiken Jüdischen Welt. Göttingen: Vandenhoeck \& Rupert. 
Edrei, A. y Mendels, D. (2012). A Split Jewish Diaspora Again - A Response to Fergus Millar. Journal for the Study of the Pseudepigrapha, 21(3), 305-311.

Elsner, J. (2003). Archaeologies and Agendas: Reflections on Late Ancient Jewish Art and Early Christian Art. The Journal of Roman Studies, 93, 115-128.

Fine, S. (2005). Art and Judaism in the Greco-Roman World. Cambridge: Cambridge University Press.

Goodenough, E. (1935). By Light, Light: The Mystic Gospel of Hellenistic Judaism. New Haven: Yale University Press.

Goodenough, E. (1940). An Introduction to Philo Judaeus. New Haven: Yale University Press.

Goodenough, E. (1953-1968). Jewish Symbols in the Greco-Roman Period (13 vols.). Nueva York: Pantheon Books.

Goodenough, W. y Neusner, J. (1988). Jewish Symbols in the Greco-Roman Period (Abridged Edition). Princeton: Princeton University Press.

Goodman, M. (2007 [1994]). Sadducees and Essenes after 70 CE. En M. Goodman (ed.), Judaism in the Roman World (pp. 153-162). Leiden: Brill.

Hayes, C. (2007). The Other in Rabbinic Literature. En C. Fonrobert y M. Jaffee (eds.), The Cambridge Companion to the Talmud and Rabbinic Literature (pp. 243-269). Cambridge: Cambridge University Press.

Heil, J. (2017). Die Konstruktion der Hispanisch-Jüdischen Geschichte der ersten Jahrhunderte - ein Versuch. Temas Medievales, 25, 39-61.

Hezser, C. y Leibner, U. (2016). Introduction. En C. Hezser y U. Leibner (eds.), Jewish Art in its Late Antique Context (pp. 1-23). Tübingen: Mohr Siebeck.

Hezser. C. (2010). Correlating Literary, Epigraphic, and Archaeological Sources. En C. Hezser (ed.), The Oxford Handbook of Jewish Daily Life in Roman Palestine (pp. 9-27). Oxford: Oxford University Press.

Laham Cohen, R. (2018). The Jews in Late Antiquity. Leeds: Arc Humanities Press.

Laham Cohen, R. (2019). La historia lacrimógena, la diáspora antes de la diáspora y los peligros de estudiar exclusivamente a los judíos. Sociedad y Religión, 29(52), 127-147.

Lapin, H. (2011). Epigraphical Rabbis: A Reconsideration. The Jewish Quarterly Review, 101(3), 311-346.

Leibner, U. (2016). Rabbinic Traditions and Synagogue Art. En C. Hezser y U. Leibner (eds.), Jewish Art in its Late Antique Context (pp. 139-154). Tübingen: Mohr Siebeck.

Leon, H. (1960). The Jews of Ancient Rome. The Social life of the Jews of Ancient Rome gleaned from the Caracomb Inscriptions. Filadelfia: The Jewish Publication Society of America.

Levine, L. (1989 [1985 en hebreo]). The Rabbinic Class of Roman Palestine in Late Antiquity. Jerusalén: Ben-Zvi.

Levine, L. (2005 [2000]). The Ancient Synagogue. The first Thousand Years. New Haven: Yale University Press.

Linder, A. (1987). The Jews in Roman Imperial Legislation. Detroit: Wayne State University.

Magness, J. (2005). Heaven on Earth: Helios and the Zodiac Cycle in Ancient Palestinian Synagogues. Dumbarton Oaks Papers, 59, 1-52. 
Miller, S. (1999). The Rabbis and the non-existent monolithic synagogue. En S. Fine (ed.), Jews, Christians, and Polytheist in the Ancient Synagogue. Cultural Interaction during the Greco-Roman Period (pp. 50-61). Londres: Routledge.

Miller, S. (2004). "Epigraphical" Rabbis, Helios, and Psalm 19: Were the Synagogues of Archaeology and the Synagogues of the Sages One and the Same?. The Jewish Quarterly Review, 94, 27-76.

Neusner, J. (1963). Jewish use of pagan symbols after 70 C.E. The Journal of Religion, 43, 285-294.

Neusner, J. (1964). Judaism at Dura- Europos. History of Religions, 4, 81-102.

Noy, D. (1993). Jewish Inscriptions of Western Europe. Vol I, Italy (excluding the city of Rome), Spain and Gaul. Cambridge: Cambridge University Press (= I JIWE).

Noy, D. (1994). The Jewish Communities of Leontopolis and Venosa. En J. Van Henten y P. Van der Horst (eds.), Studies in Early Jewish Epigraphy (pp. 162-182).Leiden: Brill.

Noy, D. (1998). Letters out of Judaea: Echoes of Israel in Jewish Inscriptions from Europe. En S. Jones y S. Pearce (eds.), Jewish Local Patriotism and SelfIdentification in the Graeco-Roman Period (pp. 106-117). Sheffield: Sheffield Academic Press.

Noy, D. y Bloedhorn, H. (eds.) (2004). Inscriptiones Judaicae Orientis, V. III Syria und Cyprus. Tübingen: Mohr Siebeck (= IJO 3).

Remling, F. (ed.) (1852). Urkundenbuch zur Geschichte der Bischöfe zu Speyer. Mainz: Kirchheim und Schott.

Rutgers, L. (1998). Recent Trends in the Study of Ancient Diaspora Judaism. En L. Rutgers, The Hidden Heritage of Diaspora Judaism (pp. 15-41). Lovaina: Peeters.

Rutgers, L. (1999). Incense Shovels at Sepphoris. En E. Meyers (ed.), Galilee Through the Centuries. Confluence of Cultures (pp. 177-198). Winona Lake: Eisenbrauns.

Sanders, E. (1992). Judaism. Practice \& Belief 63 BCE - 66 CE. Londres: SCM.

Sandmel, S. (1970). An Appreciation. En J. Neusner (ed.), Religions in Antiquity. Essays in Memory of Erwin Ramsdell Goodenough (pp. 3-17). Leiden: Brill.

Schwartz, S. (2001). Imperialism and Jewish Society. 200 B.C.E. to 640 C.E. Princeton: Princeton University Press.

Schwartz, S. (2002). Rabbinization in the Sixth Century. En P. Schäfer (ed.), The Talmud Yerushalmi and Graeco - Roman Culture III (pp. 55-69). Tübingen: Mohr Siebeck.

Smith, M. (1967). Goodenough's Jewish Symbols in Retrospect. Journal of Biblical Literature, 86, 53-68.

Talgam, R. (2014). Mosaics of Faith. Floors of Pagan, Jews, Samaritans, Christians, and Muslims in the Holy Land. Jerusalén: Yad Ben Zvi.

Urbach, E. (1959). The Rabbinical Laws of Idolatry in the Second and Third Centuries in Light of Archaeological and Historical Facts. Israel Exploration Journal, 9(4), 229-245.

Van der Horst, P. (2014). Saxa Judaica Loquuntur. Lessons from Early Jewish Inscriptions. Leiden: Brill.

Vitto, F. (1981). The Synagogue at Rehob. En L. Levine (ed.), Ancient Synagogues Revealed (pp. 90-94). Jerusalén: Israel Exploration Society.

Yuval-Hacham, N. (2019). Art and Identity in Late Antique Synagogues of the RomanByzantine Diaspora. Arts, 8(164), 1-18. 


\section{Notas}

1 Sobre el debate en torno al carácter del judaísmo tardoantiguo, en términos de unidad, multiplicidad o atomización, es aún válido Rutgers (1998). El autor, si bien reconoce las posibles particularidades de cada espacio, tiende a afirmarse en la idea de cierto judaísmo común, similar al planteo de Sanders para el periodo previo (1992).

2 Para evitar largas digresiones utilizaremos el concepto de Diáspora, aunque somos conscientes de las potenciales implicancias que posee. Reenviamos a Laham Cohen (2019).

3 Sobre la noción de judío hermenéutico, véase Cohen (1999): "In order to meet their particular needs, Christian theology and exegesis created a Jew of their own, and this book investigates the medieval history of such a hermeneutically and doctrinally crafted Jew, from Augustine of Hippo to Thomas Aquinas. In prior publications I have studied the contribution of Dominican and Franciscan friars to Christian perceptions of Jews and Judaism in the High Middle Ages; here I examine key chapters in the earlier history of the 'hermeneutical Jew' that is, the Jew as constructed in the discourse of Christian theology, and above all in Christian theologians' interpretation of Scripture" (pp. 2-3). Se han acuñado múltiples categorías en la misma línea: judío retórico; judío teológico; judío espectral; judío de papel, etc.

4 Sobre el problema de las fuentes judías del período en general, reenviamos a Hezser (2010) y a Laham Cohen (2018, pp. 4-12).

5 Nos referimos a las imágenes de Fortuna y Victoria en uno de los cuartos de la catacumba judía de Vigna Randanini. No hay dudas del uso judío del espacio (se hallaron inscripciones y tumbas, incluso de tipo koch, en el interior) pero hay controversia en torno a si las representaciones fueron pintadas (o encargadas) por judíos o, simplemente, cuando avanzaba la catacumba dieron con un hipogeo pagano y lo reutilizaron. Sobre este aspecto, véase Cappelletti (2006, pp. 151-159). Vale la pena remarcar, más allá del debate, que quienes usaron tal espacio preservaron las imágenes. También se ha debatido sobre los sarcófagos, con representaciones paganas, hallados en las catacumbas judías.

6 Vale la pena recordar que los primeros trabajos sobre las catacumbas judías de Roma las consideraban más tempranas.

7 Aunque en otras regiones de Europa se detectaron referencias a rabinos tardoantiguos, los hallazgos fueron llamativamente escasos y de temporalidad tardía. Si bien la datación de la epigrafía judía tardoantigua no es precisa, la referencia más antigua a un rabino en Europa se encuentra en Chipre (3 IJO, Cyp 1) y ha sido datada hacia los siglos III y IV. Véase Noy y Bloedhorn (2004). Para Italia, la más antigua es de Brusciano, ca. IV-V (I JIWE 22). Sólo se hallaron, en toda Europa y con anterioridad al siglo IX, cuatro inscripciones más con menciones a rabinos: I JIWE 36 (Nápoles, ca. V-VI); I JIWE 86 (Venosa, ca. VI); I JIWE 183 (Tarragona, ca. V-VI) y I JIWE 186 (Tarragona, ca. V-VI). Para las inscripciones judías de Europa occidental (excepto la ciudad de Roma), véase Noy (1993). Incluso en la propia Palestina los rabinos epigráficos, tal como los denominó Shaye Cohen, eran escasos (aunque no tanto como en la Diáspora) y se generó un intenso debate sobre si se trataba de un mero título honorífico o de sujetos pertenecientes al movimiento rabínico. Véase Cohen (1981) y Lapin (2011). Cfr. Miller (2004) y Hezser (2010, p. 23), quienes pusieron en duda las tesis minimalistas de Cohen e intentaron resaltar ciertas evidencias epigráficas e iconográficas de Palestina que indicarían injerencia rabínica en la sinagoga.

La mayoría de las inscripciones itálicas del siglo IX fueron halladas en Venosa y estudiadas por Cesare Colafemmina. Véase, entre otras publicaciones del autor, Colafemmina (2000). Vale aclarar que todas las inscripciones registradas fueron halladas de modo aislado, hecho que puede generar un sesgo importante en la evidencia dado que sólo se reconocerán como judías aquellas en lengua hebrea o con marcadores explícitos. De todos modos, es cierto que en las catacumbas romanas y venosinas del período previo no se encontró ninguna inscripción plenamente en hebreo ni con referencias talmúdicas. 
9 Es aún válida la compilación y traducción de leyes sobre judíos en el Código Teodosiano realizada por Linder (1987).

10 El documento fue compilado por Remling (1852, pp. 57-58).

11 Sobre los minaguim (costumbres/hábitos/prácticas) haremos referencia más adelante, cuando presentemos la posición de Schwartz sobre la rabinización de la diáspora.

12 Hezser (2010, p. 23): "Nowadays hardly any scholar would share the view that there was such a harsh opposition between 'the rabbis' and 'the people' in late Roman Palestine”. Nótese que la autora proyecta sobre quienes aspiran a reconstruir el judaísmo no-rabínico el uso de la dicotomía rabínico/popular, hecho que simplifica en exceso posiciones como las de Goodenough. Sobre este aspecto volveremos más adelante.

13 Véase, en una línea similar, Baumgarten (1999).

14 Sobre grupos judíos no rabínicos, véase, entre otros, Hayes (2007). Más adelante nos referiremos a la perspectiva, sostenida por diversos autores, de supervivencia del sacerdocio jerosolimitano.

15 Goodman (2007 [1994], p. 161): "Let me put my suggestion clearly but crudely. My hypothesis is that groups and philosophies known from pre-70 Judaism continued for years, perhaps centuries, after the destruction of the Temple".

16 En tal sentido han avanzado, entre otros, Miller (2004), Hezser (2010) y Leibner (2016). El hallazgo de la sinagoga de Rehov en 1973, con una inscripción claramente rabínica (de datación problemática, pero en general ubicada en torno al V), fue un elemento importante para que ciertos investigadores recalibraran la injerencia rabínica en la sinagoga. Véase Vitto (1981).

17 Vale aclarar aquí una posibilidad: que la rabinización de la Diáspora haya progresado en paralelo a la de Palestina. Es decir, que el movimiento rabínico haya ingresado tempranamente en la Diáspora y avanzado gradualmente, al igual que en la Tierra de Israel, en lugar de haberse consolidado allí y luego ser "exportado". No es una tesis descabellada aunque, desde nuestra perspectiva, la falta de evidencias diaspóricas de rabinización temprana va contra tal idea.

18 Se trata de un análisis excelente. Sin embargo, desde nuestro punto de vista, asocia con demasiada insistencia y cierto reduccionismo la postura de cada autor con su contexto de producción. Véase también la introducción de Hezser y Leibner a su libro sobre arte judío tardoantiguo (2016).

19 En total se publicarían 13 volúmenes, el duodécimo en el año de la muerte del investigador. El decimotercero está conformado por índices y mapas, y fue publicado en 1968.

20 En torno a la dificultad de hablar de "arte judío" en el período, véase Elsner (2003).

21 Recientemente, Yuval-Hacham (2019) señaló que Dura Europos es el único sitio diaspórico (además, de datación temprana) con abundantes representaciones humanas, mientras que en el resto de la Diáspora primaron los diseños geométricos. Para la autora, este aspecto se explicaría por la mayor violencia e inseguridad detectada en la Diáspora, hecho que habría llevado a los judíos de tales regiones a evitar diseños que pudieran generar polémica. Si bien consideramos errónea tal visión, no la debatiremos aquí. Debemos recordar que, aunque controvertidas, en las catacumbas judías de Roma aparecieron representaciones antropomórficas (divinas, incluso) y que sinagogas como las de Naro poseían representaciones de animales. Hay debate, incluso, por la presencia de una imagen de Daniel en la sinagoga de Sardes. Por otra parte, la menor cantidad de sitios hallados en la Diáspora pone en tela de juicio cualquier generalización.

22 Goodenough ya tempranamente había escrito sobre Filón, misticismo y mundo helenístico. Véase, por ejemplo, Goodenough (1935 y 1940).

23 Sobre las críticas y cómo las vivió Goodenough, véase el interesante (y crudo) aporte de Sandmel (1970) en el libro homenaje a aquel. Entre sus críticos, se destacaron Urbach (1959), Bickerman (1965) y Smith (1967). Recibió, por su parte, el apoyo fundamental de Neusner (1963 y 1964). El mismo Neusner (1988) reeditaría, aunque en un texto fuertemente abreviado, Jewish Symbols.

24 Goodenough (1965, v. 12, p. 186): "And since many of our best scholars have insisted that Philo can by no means be taken as typical of Jews even in Alexandria (with which I 
agree), I counter that the writings of the rabbis can similarly not be asumed to represent the Judaism of all Jews even in Palestine".

25 La referencia es al pavimento de mosaicos descubierto en 1961 en la sinagoga de Hammat-Tiberias. Allí se encontró otro disco zodiacal en cuyo centro aparecía Helios con un orbe en la mano, figura explícitamente prohibida en la literatura rabínica. El hallazgo, en medio de la publicación de Jewish Symbols, dio nuevas fuerzas a los planteos de Goodenough.

26 Goodenough, en los primeros volúmenes, insistió fuertemente en el carácter místico de aquel judaísmo no rabínico. Con el correr de la obra, si bien mantuvo su postura, esmeriló, aunque muy parcialmente, tal aspecto.

27 Valgan las adecuadas palabras de Schwartz (2001, p. 134) sobre la "filonización” del arte por parte de Goodenough: "Goodenough adopted a different sort of judaizing approach to the material. In contrast to the Avi-Yonah school, which rabbinizes, by supposing that if an image was not likely to have been worshiped then it was purely decorative, absolutely devoid of religious meaning, and thus unproblematic from the Jewish perspective, Goodenough 'Philonized'. For Goodenough, even geometric designs, rosettes, and so on, were packed with religious meaning”.

28 Bien observado por Fine (2005, p. 38).

29 Recordemos, por ejemplo, la crítica indirecta de Hezser que expusimos en la nota 12. Vale remarcar, también, que la idea de una elite no rabínica continúa siendo resistida por una parte importante de la crítica. Por ejemplo, Talgam (2014, p. 294): “Separating synagogue decorations such as those of Sepphoris from the world of the sages posits the existence of an intellectual elite that formed an alternative leadership group to that of the sages, a claim I find difficult to accept".

30 Es cierto, sin embargo, que en algunos pasajes de su texto Leon utilizaba el Talmud acríticamente. Por ejemplo, cuando equiparaba archisinagogo con Rosh Ha-Kneset (p. 171).

31 David Noy (1994, p. 176), evaluando la misma evidencia epigráfica, llegará a conclusiones diferentes: "It looks as if the exclusive use of the Hebrew language and the predominantly Hebrew naming system of the 9th century are something new, not a continuation of any 6th-century development".

32 De todos modos, Levine (2005, p. 496) fue cauteloso y consideró que, al menos para Palestina, la influencia rabínica en la zona creció a partir del siglo III e.c.

33 También se vislumbraba, según Levine, en ciertos elementos de la liturgia como los piutim (poemas litúrgicos que hicieron su aparición en la Tierra de Israel durante la Antigüedad Tardía y que, en general, son asociados a la rabinización).

34 Vale aclarar que Schwartz tampoco citaba el trabajo de Colorni.

35 La existencia de una costumbre que no puede ser catalogada como rabínica en el siglo XI puede ser indicio de prácticas populares originadas en el marco de comunidades ya rabinizadas. No obstante, y como ha sugerido una parte de la crítica, puede también implicar la supervivencia de una tradición europea previa a la rabinización.

36 Tal posición se encuentra en línea con múltiples trabajos, entre los que resaltan las plumas de Seth Schwartz, Israel Yuval y Daniel Boyarin (sólo para nombrar a los más conocidos), en relación con el impacto que generó en el judaísmo el nacimiento del cristianismo.

37 Magness (2005, n. 129, p. 22) considera que las posiciones de Levine y Rutgers, quienes dudaban de que el poder sacerdotal hubiera impactado en la Diáspora, eran erróneas. Sin embargo, no justifica las causas de su rechazo. Por su parte, Rutgers (1999, p. 196) había afirmado: "This serves as a reconfirmation of what literary and epigraphic sources likewise indicate - namely that, in Late Roman and Byzantine Palestine, descendants of priests continued to make a mark on society in general and on the synagogue in particular while, in the diaspora, priests simply were never a force with which to reckon".

38 A Goodenough sólo lo citaron en su segundo artículo (2008), dado que Moody Smith les había criticado, en su comentario al primer artículo, la omisión. Ellos respondieron que no acordaban con Goodenough respecto de negar la posibilidad de que los rabinos aceptaran la iconografía hallada en sinagogas, pero olvidaron que el mismo Goodenough había ya iluminado las diferencias lingüísticas que ellos tornaban como 
eje de su investigación. Colorni no es mencionado por los autores en ninguno de los textos aquí citados; omisión problemática, dado que el italiano había sido contundente al momento de marcar las diferencias lingüísticas entre las diásporas.

39 En el artículo original, Egipto recibía, en una nota al pie, un trato particular. De hecho, en la respuesta dada en 2012 a las críticas de Fergus Millar remitían a tal nota y a su libro donde ya habían expandido tales tibios matices iniciales.

40 Edrei y Mendels están convencidos de que los judíos de la Diáspora occidental no produjeron material memorable: "It is more logical to assume that during this period the Jews did not produce significant literary works" (2008, p. 166). Los autores rechazan la idea de que la Iglesia pudo haber destruido toda la producción judía dado que, en sus palabras, no pudo hacerlo ni siquiera en períodos posteriores, de mayor persecución y poder. Olvidan, sin embargo, que la transmisión de textos depende de múltiples variables que no sólo incluyen la violencia ejecutada por agentes externos. Las propias comunidades rabinizadas pudieron, de hecho, haber discontinuado la copia de textos que ya no consideraban pertinentes.

41 Basten algunos pasajes para ver que el enfoque es el mismo: "In dem vorliegenden Buch wollen wir diesen Gegenstand erneut untersuchen und deutlich machen, dass die Trennlinie zwischen östlischer un westlischer Diaspora nicht lediglich geografischer Natur war, sondern in Wirklichkeit sehr viel tiefer ging" (p. 9). "Wir behaupten, dass die sprachliche Kluft zwischen den beiden Diasporas eine weit tiefere kulturelle Kluft nach sich sog, als man gemeinhin annimmt, und darüber hinaus zu zwei normativen Systemen führte, eines im Osten und eines in Westen" (p. 10). "Während sich im Osten ein neuer Normenmaßstab, die mündliche Lehre, entwickelte, blieben die jüdischen Gemeinden im Westen der Bibel verpflichtet und hielten an der Tradition fest, wie sie vor dem Aufstieg der Rabbinen und ihrer Lehren vorherrschte” (p. 40).

42 Si bien los artículos no fueron muy visibilizados y cosecharon más críticas que halagos, el especialista en epigrafía judía antigua Pieter Van der Horst (2014, p. 65) no dudó en considerar válidas las conclusiones de los autores: "In this connection it is important, however, to stress the major difference between the Eastern and Western diasporas. The linguistic divide between the two (a Semitic speaking diaspora in the East, a Greek speaking one in the West) had dramatic consequences. It is not only the fact that the rabbis handed down their halakhah in an oral form for a long time but also and especially the fact that, once these traditions were finally written down, they never took the trouble to translate their Mishnah, their Talmudim, and their midrashim into Greek (let alone Latin) that prevented them from gaining influence in the Western diaspora. The language gap was not bridged and the consequence was that the rabbis thus lost half of their constituency. Jewish communities in the West, isolated as they were from the rabbinic network, could not contribute anything to the development of halakhah in the East. This situation changed only in the Middle Ages when, around the ninth century, the rabbinic movement arrived in Greek and Latin Europe”. En nota al pie luego de estas palabras, Van der Horst se refería a los trabajos de Edrei y Mendels.

43 En la misma línea, y en tiempos de confección del Talmud de Babilonia, ciertos rabinos locales afirmaron que ellos poseían un linaje más puro que aquellos que se encontraban en la Tierra de Israel.

44 A Goodenough ni siquiera lo cita. Es cierto que, pasados ya tantos años de su obra, es posible que ya la haya considerado superada. Sin embargo, no referirse a la obra en un texto que, precisamente, trata sobre la expansión rabínica sigue siendo, desde nuestro punto de vista, una omisión no justificada.

45 En contra de Collar también se expresó Van der Horst (2014, p. 59): “This is in such a marked contrast to the eastern Aramaic-speaking diaspora that some scholars speak of a split diaspora, a Semitic-speaking diaspora that was dominated by rabbis in the East and a non-rabbinic Greek-speaking diaspora in the West. Be that as it may, recent attempts to demonstrate that soon after 70ce also the Western diaspora came under rabbinic sway are in my view utterly unconvincing. The vast majority of the Jews in the Roman Empire never saw a rabbi and never heard of the Talmud".

46 Noy (1998), centrándose en la epigrafía pero también en el registro literario, también enfatizó la persistencia de contactos entre la Tierra de Israel y la Diáspora. 
47 Aquí Heil hace equilibrio entre las posiciones de Wasserstein y Del Valle en torno a la existencia de una literatura judía en la Hispania tardoantigua y, de aceptarse tal existencia, en relación con la lengua en la que fue constituida. 